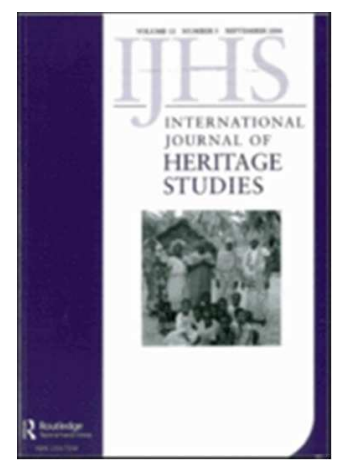

\title{
Space is the Place: European jazz festivals as cultural heritage sites
}

\begin{tabular}{|r|l|}
\hline Journal: & International Journal of Heritage Studies \\
\hline Manuscript ID & RJHS-2018-0199.R2 \\
\hline Manuscript Type: & Original Article \\
\hline Keywords: & Jazz, Festivals, Europe, Cultural Heritage \\
\hline \multicolumn{3}{|c}{} \\
SCHOLARONE \\
Manuscripts
\end{tabular}




\begin{abstract}
The JPI-Heritage Plus supported Cultural Heritage and Improvised Music in European Festivals (CHIME) project was established to examine the workings of jazz festivals and their relationship to cultural heritage as discursive practice. Jazz festivals occupy a significant - if undervalued - place in the ecologies of Europe's cultural heritage, with their dynamic and synergetic relationship to spaces and cultural sites. Drawing on a number of case studies and interviews with members of the Europe Jazz Network, this article presents a typology of European jazz festivals and cultural heritage sites that can be used to inform the different ways in which jazz offers meaning to specific groups and locations. By viewing jazz festivals through the lens of cultural heritage, we can begin to challenge reified presentations of heritage that promote uncomplicated interpretations of nations, people and their associated cultural narratives. Festivals offer meaning to specific groups through acts of remembrance or commemoration, they have the potential to engage with a multitude of voices, and their locations enable people to negotiate a sense of belonging or to (re)consider their place in the world.
\end{abstract}

Keywords: jazz; festival; Europe; cultural heritage 


\section{Introduction}

Heritage is a contested subject that is bound up with concepts of memory, belonging, and cultural value, as well as politics of power, history and ownership. As Laurajane Smith (2006) stresses, heritage is not only about celebrating and appreciating the value of material things that have been passed on from one generation to the next but it is also a communicative act that encourages people to make meaning for the present day. Despite the contention, often found in discourses surrounding cultural heritage today, that anything can be heritage given the right context, clear tensions remain between official versions of heritage that promote national culture as a fixed entity and the more vernacular and unofficial expressions of people, places, histories and marginalised communities. Indeed, Stuart Hall's widely cited discussion of the problems of "The Heritage" (1999) continues to have resonance today, when the promotion of a reified national heritage remains popular among politicians, policy makers and institutions charged with the protection and promotion of official sites and monuments. For Hall, "The Heritage" becomes "the material embodiment of the spirit of a nation", it is a collective representation of tradition or of valuable places and objects that, " $[\mathrm{t}] \mathrm{o}$ be validated, must take their place alongside what has been authorised as 'valuable' on already established grounds in relation to the unfolding of a 'national story' whose terms we already know" (3-4). These reified presentations of heritage can structure ideas not only about the past but can also play down, ignore or exclude issues of race, gender, class, and disability that would inevitably provide a challenge to official and uncomplicated interpretations of nations and associated cultural narratives. Despite a number of changes to understandings and approaches to heritage research in recent years, and the acknowledgment of bottom-up approaches to heritage (Zanten 2004), ideas of nationhood can often remain naturalised and colonial histories treated as remote and unproblematic.

Whilst there has been an absence of popular music studies in traditional debates about heritage, the past ten years in particular have witnessed an increase in scholarship examining the relationship between music and heritage. Indeed, in more recent studies, popular music has provided an interesting platform to examine the relationship between tangible and intangible heritage, the development of individual and collective identities, and the interplay between top-down and bottom-up formations of culture (Bennett 2009; Cohen 2012; Brandellero \& Jansen 2014). However, whilst popular music studies have recently engaged meaningfully with discourses around heritage, jazz scholarship has rarely moved beyond discussions of the music's constructed tradition (Williams 1988; DeVeaux 1990), studies of local histories, scenes and venues (Heller 2017) and the examination of the music's relationship to New Orleans (Sakakeeny 2013; Boyd Raeburn 2009). Despite the interest in charting the history of jazz in specific locations as well as the music's aesthetic transformation over time, this research has not been placed within the broader field of heritage studies and the discourses that surround the relationship between music, people and place. When jazz is examined in relation to European cultural heritage, therefore, it feeds into a set debates about cultural value and influence that have remained under-investigated, from discussions about the 
${ }^{1} \mathrm{EJN}$ is the primary Europe-wide association of producers, presenters and supporting organisations who specialise jazz and improvised music. As of April 2018, their membership includes 133 organisations spanning 35 countries. See www.europejazz.net

relationship between jazz and folkloric traditions (how much is European jazz practice understood as an expression of different European nations) to the migratory influence, including issues of appropriation and enculturation (for example, how the African American tradition has interacted with European culture). The presence of jazz feeds into discussions of music as a racialised and gendered discourse, as well as the shifting cultural status of art forms. Indeed, jazz in Europe today challenges traditional distinctions between high culture and vernacular practices, as the music exists in both concert hall settings and a range of underground venues, bars, clubs and everyday contexts. Given its colourful history in Europe, jazz has functioned as a sounding board for social change and fed into different cultural debates and political contexts, from the civil rights movement to the cold war. Furthermore, the music has been, and continues to be, used as a tool for cultural diplomacy and propaganda as demonstrated through the mission of the US Ambassador Programme of the 1950s and 60s to the more recent formation of UNESCO's International Jazz Day in 2011 (Von Eschen 2006; Davenport 2013). When jazz is performed in different European locations, the music feeds into a series of complex questions about cultural heritage. The music can be a crucial element in disrupting established ways of thinking about heritage; when jazz enters particular spaces, it can provide a means of engaging with established discourses, reconfiguring histories, encouraging a renewed perspective on a particular location or community, and re-engaging with the past.

\section{Jazz Festivals}

Building on these ideas, the JPI-Heritage Plus supported Cultural Heritage and Improvised Music in European Festivals (CHIME) project was established to examine the workings of jazz festivals and their relationship to cultural heritage as discursive practice. Jazz festivals occupy a significant - yet undervalued - place in the ecologies of Europe's cultural heritage, with their dynamic and synergetic relationship to spaces and cultural sites. CHIME sought to highlight different ways in which jazz festivals interacted with - and challenged - concepts of cultural heritage and explored places that had become symbolic of particular social and cultural events, where values and meanings have been ascribed and where identities continue to be constructed, re-constructed, suppressed or negotiated. CHIME examined places that encouraged people to reflect on their relationship to the environment and where jazz played a specific role in promoting the values and identities of specific groups. Working primarily with members of Europe Jazz Network (EJN), the project team looked more broadly to places of significance, where acts of remembrance or commemoration offered meaning to specific groups, to locations where people negotiate a sense of belonging or could (re)consider their place in the world. ${ }^{1}$ As a way of capturing this significance, the range of case studies explored within the 
CHIME project revealed a typology of European jazz festivals and cultural heritage sites that can be used to inform the different ways in which jazz offers meaning to specific groups and locations. For this article, therefore, I would like to explore some of the themes and issues linked to this process and to present a provisional typology of jazz festivals and their relationship to tangible and intangible cultural heritage.

\section{Materials and methods: Towards a Typology - festivals, communities, and the problems of sameness}

Allessandro Falassi's widely cited article "Festival: definition and morphology" outlines the genealogy of the term festival and also discusses a general typology of festivals - be they sacred, secular, rural, or urban. Falassi describes how festivals can articulate class structures, power relationships, and different social roles, and describes how they can embody a range of rituals, from rites of passage to rites of renewal. Whilst the development of the CHIME jazz festivals typology clearly takes some of these generic descriptions and concepts into account, I am more interested in examining ways in which festivals feed into discourses around heritage; how jazz festivals speak to different communities, construct narratives about themselves, and engage meaningfully with contrasting - and sometimes competing - forms of cultural heritage. Fallasi defines the festival thus:

[A] periodically recurrent, social occasion in which, through a multiplicity of forms and a series of co-ordinated events, participate directly or indirectly and to various degrees, all members of a whole community, united by ethnic, linguistic, religious, historical bonds, and sharing a worldview. $(1987,2)$

Whilst this definition provides us with a framework for understanding the general meaning and uses of the word festival, when looking at this statement in relation to jazz festivals, several problems arise, most notably the question of what constitutes a community and also knowing what particular worldview is being expressed through festival events. There is an idealised sense within definitions such as these that each festival is unique or that it presents a coherent mission, when, in fact, festivals often reflect the desires and tastes of different people; they can often contain conflicting messages and curatorial decisions, and can appear to mirror other festivals and formats from around the world. One of the early tensions we found within the CHIME project was the feeling that there was a lack of uniqueness among many jazz festivals today. In several cases, there was a similarity - or a bland cosmopolitan character - to many international jazz festivals, where the same acts were presented night after night performing at different festivals around Europe. Indeed, in Europe, the economics of staging events is often dependent on festivals agreeing to share costs and to support the work of touring artists from overseas.

Another tension within the project was the discrepancy between idealised constructions of jazz and experiences on the ground. For example, in making the case for the project we argued that, when jazz enters particular places, it can offer a resounding of the past; the music can provide a challenge to unitary or reified notions of 
heritage and can encourage us to engage with cultural heritage in new ways. In preparing for the project, we drew on a quotation from Chris Goddard's book Jazz Away From Home, where he describes one experience of listening to music in the amphitheatre during the Nice Jazz Festival as "having a rough edge to it that cuts through the warm, humid Mediterranean night like a chain saw through cheese" $(1979,228)$. And yet, at an early stage in the project, one of the team asked, "does jazz really have the same provocative chainsaw qualities as, say, punk or other musics that actually involve using chainsaws on stage?" Equally, when project team members began to undertake fieldwork as part of the project, our idealised constructions of jazz audiences and practices sometimes met with different festival experiences on the ground. There was often an unease when encountering the comfort and luxury of festival events and the wealth and class status of many audiences; the hip, radical and progressive imaginary being undermined by greying hairstyles, an abundance of comfy chairs designed for the over $50 \mathrm{~s}$, extortionately high ticket prices, VIP areas for corporate sponsors, and nostalgia-driven acts dominating programmes. From this, the question of what constitutes the jazz community - or the jazz festival community - emerged, and answers to this are by no means straightforward. As Ken Prouty outlines in his book Knowing Jazz (2013), the jazz community is an often-touted term that assumes uniformity and coherence when in fact the concept is fragmented; there are multiple jazz communities and it would be difficult to identify a uniform worldview among different interest groups given the dispersed nature of audiences, diverse age groups, and the range of music that falls beneath the banner of jazz. From this, we have the situation where many festival programmes appear to offer similar content whilst audiences for events are not necessary readily identifiable as a coherent group. In his study of festivals and the public cultural sphere, Motti Regev draws on the Red Sea Jazz Festival in Israel as one example of a festival whose audience is drawn from members of what he describes as "omnivorous taste cultures"; namely middle class audiences who define their sense of taste by consuming goods and works of art from a wide range of cultural contexts. Whilst Regev's description of Red Sea might seem like a relatively typical European festival environment, the role of jazz within an Israeli national context is significant. Regev argues that the promotion of aesthetic cosmopolitanism through the work of an international festival has the potential to contribute to meanings of national culture and, therefore, by their very nature, jazz festivals can challenge limited presentations of nation through an orchestrated series of outward facing events $(2011,109)$. What we need to consider here is how the same acts can offer a sense of difference, a re-sounding of jazz when they appear in different spaces. By examining festivals through the lens of cultural heritage discourse, we can begin to understand differences between festivals that might, on the surface, appear indistinguishable. This approach takes into account local knowledge, cultural politics, and the specific values of different communities and stakeholder groups. Here, we can consider how the same line-up and concert programme generate different meanings depending on the cultural and political context and mission of the festival - indeed, even within a single festival, different uses and understanding of events clearly occur, 
whether you are an artist, audience member, outdoors, indoors, or one of the privileged few invited to the VIP lounge. As in the case of Red Sea, even when the festival attracts a middle class following from "omnivorous taste cultures", it is important to explore how much jazz can still encourage us to re-engage with history or to offer alternatives to established national narratives and mythologies.

When drawing up a typology of jazz festivals and cultural heritage sites, therefore, it was important to grapple with the issue of sameness, and to attempt to understand how festivals that appear indistinguishable in terms of programme content can indeed be distinguished from each other through the discourse of cultural heritage. As Project Leader for the CHIME project, I worked alongside a team of researchers working in The Netherlands, Sweden and UK to examine different ways in which festivals used and re-used cultural heritage. The project involved historical and archival research, ethnographic fieldwork, audience engagement activities and qualitative interviews with festival organisers and liaison with the broader membership of EJN. This mixed methodology informed the analysis of festival events and the different ways in which they engage with heritage issues.

\section{Results: Typology}

Following this mixed methods approach to the study of European festivals, I developed a typology of jazz festivals that attempts to illustrate how cultural heritage themes play out in different European settings. When examining festival missions and discussing ideas with festival organisers, it was clear that ideas of cultural heritage were not always articulated or understood by festivals themselves. Therefore, the following categories should not be seen as absolute or exhaustive but as a starting point for discussion and understanding the ways in which European jazz festivals can engage with cultural heritage themes. These categories seek to balance the tangible and intangible within festival settings, and illustrate differences between heritage sites - the spaces where music happens - and a broader discourse around cultural heritage and the relationships people have to music and place, past and present. Indeed, given the transient nature of festivals and the variety of spaces used and themes that emerge, several European jazz festivals fall within more than one of the following categories. With this in mind, the typology is designed more as a tool for thinking about jazz festivals and their relationship to cultural heritage. Whilst several categories lend themselves to debate about heritage issues, others map the different places where jazz happens across Europe.

\section{Ancient places/Archaeological sites}

Several European jazz festivals have used ancient sites as part of their cultural offer. Indeed, within the early years of its development, the Nice Jazz Festival acknowledged as the first international jazz festival established in 1948 - drew extensively on the amphitheatre within the city to showcase some of its headline jazz events. Equally, festivals such as Jazz à Vienne continue to use their amphitheatre today. Festivals that take place in ancient sites can highlight tensions between 
different forms of cultural heritage and have inevitably developed a greater sensibility around the relationship between conservation and use.

\section{Historic towns and buildings}

A large number of European jazz festivals take place in the picturesque settings of historic towns and buildings. Here, we might think of the spa town of Cheltenham in the UK with its regency mansions or the hamlet of Coutances in France as historic places where jazz can provide both a contrast and complement to the history and architecture of the town. In the UK in particular, there has been strong relationship between jazz and the stately home, as evidenced through the establishment of the first jazz festival in Britain in 1956 at the Beaulieu estate, home of Lord Montagu. As George McKay states:

...Beaulieu, like Woburn in the 1960s and the better-known Knebworth Festivals of the 1970s, began a connection of aristocratic privilege and popular music, of private means and mass entertainment, that characterised a certain social stratum of those swinging times. "A combination of blue blood and the blues" was the Beaulieu motto in 1957, while a banner over the festival stage read, "Harmless amusement for all classes." $(2005,73)$

Whilst the relationship between jazz and stately homes might appear synergetic, the non-conformist qualities of the music still have the potential to disrupt the seemingly cosy relationships between wealth, privilege and subcultural interests. The 1960 Beaulieu Festival, for example, ended in a riot as rival jazz fans clashed over musical taste, accentuating differences in age as well as class interests and agendas. McKay comments on the way in which the carnivalesque spirit of festivals can imbue transgressive behaviour in people and suggests that incidents such as these demonstrate how the widespread idea of jazz as a universal language fails to acknowledge the music's power to ignite conflict in different parts of the world $(2005,77)$.

\section{UNESCO World Heritage Sites and Cities of Music}

Given UNESCO's commitment to celebrating jazz as a universal language through its International Jazz Day initiative, it is perhaps unsurprising that several jazz festivals take place within the context of UNESCO world heritage sites and musical cities. The World Heritage site certainly provides a grandeur and spectacle for jazz that serves to enhance the musical experience for festival-goers. One only needs to think about the Ta' Liesse festival in Malta and its stunning location situated just beneath the bastions surrounding the World Heritage City of Valetta or the numerous jazz festivals that occupy almost every Italian town and heritage site. Equally, the presence of jazz can also contribute something to the profile of UNESCO sites; the presence of jazz in Glasgow, for example, enriches the cultural offer of the city and provides a contrast to stereotypical understandings of what a UNESCO City of Music should sound like in Scotland. UNESCO World Heritage sites that include conservation areas 
and places of natural beauty are also included in the European jazz festival offer. For example, successful festivals such as Molde International Jazz Festival in Norway have made use of the festival's relationship to the Western Fjords in their creative programming over the years. For example, regular festival events such as "Break of Day in Molde," are programmed outdoors, at sunrise, in order for audiences to experience jazz working in synergy with nature. Whilst clearly providing audiences with a novel means of engaging with music, these events can also feed into broader, more problematic, constructions of national sound. In recent years, for example, the concept of the Nordic Tone has become a major tool for promoting Norwegian jazz, as journalists and record labels have explicitly linked folkloric sounds to both mystical landscapes and national stereotypes (Nicholson 2005; Lake and Griffiths 2007). Here, festival events, and the broader music industry, can feed into mythmaking processes and support both imaginary and essentialist constructions of nationhood (Whyton 2012).

\section{Landscapes, social responsibility and the natural environment}

Molde is not the only festival that attempts to engage audiences with landscapes and the natural environment, building music into the experience of the natural environment. At the Südtirol Jazzfestival in the South Tyrol, for example, musicians ascend the heights of the mountains, with instruments on their backs, to entertain the public against a breath-taking Alpine backdrop. In recent years, by several festivals have sought to engage with environmental issues and promote awareness and a "greener" behaviour among audiences. A number of European jazz festivals now have green policies and demonstrate a commitment to sustainable living and protecting the natural environment. Famous and long-established festivals such as Montreux, which occupies a beautiful lakeside location in Switzerland, have developed clear policies around sustainable development and social responsibility. For example, measures include the commitment to returning the site to its original state on a daily basis; employing a team that works 24 hours a day to sort through trash and ensure the cleanliness of the festival areas, utilising an eco-compatible waste plant, and providing information for the public to promote eco-friendly measures. Montreux has also created a space within the lakeside area of the festival site to promote social responsibility, enabling organisations to offer advice on drink awareness, avoiding anti-social behaviour and educating audiences about environmental issues. In a broader context, Europe Jazz Network has developed the "Take The Green Train" initiative that seeks to foster collective action in tackling climate change and environmental degradation. "Take The Green Train" activities have included the production of a green manifesto for the network that encourages its members to address their own environmental impacts and to raise the status of sustainability and environmental issues within the jazz community, and the productions of a green tourism scoping study. ${ }^{2}$

${ }^{2}$ For further information see http://www.europejazz.net/activity/take-green-train. 


\section{Post-Industrial spaces}

Several European festivals employ post-industrial spaces as part of their offer. There is now a large network of post-industrial venues around Europe that provide alternative spaces for creative artists and festivals ranging from the Old Fruit Market in Glasgow to the Vooruit Co-operative building in Ghent, from the Tou Scene brewery in Stavanger to the former slaughterhouse in Bremen, which provides a central venue for the Jazzahead festival and industry expo that takes place annually. The slaughterhouse provides a perfect example of how the convergence of space and place can encourage people to think about the contested cultural heritage of Europe. Built in 1892, the Slaughterhouse was prevented from demolition in the late 1970s. Since its transformation in the 1990s, it has become the largest cultural centre in Bremen, an impressive post-industrial venue with bars, a cafe, and an amazing performance space that is ideal for jazz and improvised music due to its acoustic, seating plan (which does not conform to conventional theatre style), and its postindustrial design. In addition to its industrial heritage, the building is also associated with Europe's troubled history. In 1943, the slaughterhouse grounds were used by the Nazis in their deportation of Roma communities from Bremen to Auschwitz, where most were murdered. A plaque was erected outside the Schlachthof in 1995 to commemorate those who suffered these atrocities. As a cultural centre, the Schlachthof engages with Bremen's cultural heritage head on and, in this context, jazz provides the perfect vehicle both to engage with the heritage of the building literally and symbolically, to re-use the site and to energise the space. In many ways, the music works as a form of cultural palimpsest where traces of history remain but the sounds created in the venue confront the building; encouraging audiences to think about the problematic past, to reflect on the resilience of humanity and the processes of healing and renewal, and to experience the power of music in bringing people together.

\section{Jazz Heritage Festivals}

Moving away from heritage sites and the physical spaces where music happens, it is also interesting to explore the way in which many European jazz festivals are engaging with jazz as a heritage music today. On the one hand, this trend could be seen to be reinforcing the canonical tradition of jazz by promoting a historicised version of the music over conceptions of jazz as a contemporary improvised practice. However, several festivals have developed particular tribute events that go beyond simple imitation and reverence of legendary artists to create a narrative-based programme that brings certain periods of jazz history to life. As part of CHIME project interviews, several festival directors discussed ideas of drawing on the history of the music as an immersive experience. The EFG London Jazz Festival, for example, has staged events that explore the historical moments and attempt to bring legendary figures to life. Recent events include Charlie Parker on Dial, an exploration of Café Society, and a celebration of the famous Benny Goodman Carnegie Hall Concert. In addition to one-off events that celebrate the musical heritage of jazz, some festivals have focused specifically on distinctive styles of jazz 
or performance practices. These festivals include the Festival Django Reinhardt in France and the Classic Jazz Festival Sweden, which presents traditional-style jazz and uses the harbour-front in Gothenburg (along with a vintage paddle-steamer venue) to evoke the imagined sounds of New Orleans.

\section{Heritage and Cultural Tourism}

Several festivals, like Palatia Jazz in Germany, are deliberately geared towards cultural tourism. Festivals often work in partnership with heritage sites, and local makers to provide visitors with an exceptional cultural experience. The jazz festival within this context forms part of a set of lifestyle activities. When I spoke with the Palatia Jazz festival Director, Suzette Yvonne Moissl, she talked about the way in which jazz provided a dramatic context for the different historic spaces; Moissl argued that there is a synergetic relationship between her festival spaces and jazz that enables people to engage with place in interesting ways; for Moissl, music and location provide access to mystical experiences and an engagement with the region's mythic past. Several festivals have been incorporated into distinctive cultural brands and tourist offers of particular places. The Islay Festival in Scotland, for example, has a direct relationship with the Lagavulin Distillery, and encourages visitors to enjoy jazz whilst sampling its famous malt whisky. Other festivals have sought to expand their tourist offer by developing their brand into other territories. The North Sea Jazz Festival, for example, offered jazz cruises as part of its programme in 2007 and, more recently, established a satellite festival was in the Dutch Caribbean Island of Curaçao, which is explored in more detail by Aggett and Van de Leur in this issue.

\section{Voices from the margins}

When examining jazz festivals and their relationship to heritage discourse, it is important to consider voices that have been previously excluded from official histories or dominant narratives. With this in mind, festivals that promote difference to the norms that have been established within a particular cultural context or events that seek to feature voices from the margins are interesting in terms of their attempts to disrupt existing values and assert new identities. Jazz has traditionally been a music linked to political struggle and the quest for civil rights, and yet, dominant histories have tended to focus on great African American men as a marker of authenticity at the expense of women and other marginalised groups. Several festivals now seek to be more inclusive with their approach to both artists and audiences and Europe Jazz Network's Jazz Balance initiative, for example, was established to "analyse the jazz scene from a norm-critical perspective". By sharing experiences and knowledge in this field, EJN developed a web-based tutorial program addressed to concert organizers, promoters and producers in order to provide advice on putting normcriticism into practice, and implementing new organizational structures, from concert bookings, to communication and marketing. ${ }^{3}$. In the case of CHIME and its partners,

\footnotetext{
${ }^{3}$ See http://www.europejazz.net/activity/europe-jazz-balance. The PRS Foundation's Keychange iniative provides a compelling example of how festivals are signing up to be more
} 
the first Women in Jazz Festival took place in Gothenburg in 2015. The festival mirrored successful events such as the Melbourne Women in Jazz Festival and was created as a response to the absence of female artists appearing in more high profile festivals in Sweden. The festival director, Marie Tarrach Bävholm, sought to offer an alternative take on the jazz scene in Sweden by creating the festival event. Whilst festivals that celebrate difference and provide a platform for voices from the margins, it should be noted that initiatives such as these continue to struggle when it comes to sponsorship and support, both in terms of raising funds and developing a brand that adequately represents marginalised groups. Even though it had a successful inaugural event, the Women in Jazz festival in Gothenburg only lasted for one edition.

\section{Sub-cultural Heritage}

Despite jazz's widespread appeal and use within top-down configurations of culture, examples remain of jazz festivals that reflect different subcultural groups; the music has been a factor in mobilising communities, providing a soundtrack to political activism (McKay 2005). The history of jazz in Europe illustrates the importance of festival as a site for social activism and political protest and, within central and Eastern Europe in particular, the music came to articulate political struggle of the complexity of the Cold War. Today, we might also consider ways in which jazz festivals feed into other forms of subcultural heritage, from jazz 'happenings' associated with grass roots collectives and DIY scenes (Gebhardt and Whyton, 2015) to events such as the Red Light Festival in Amsterdam that promotes synergies between jazz and the sex industry. This latter example illustrates how jazz can continue to confronted social taboos by challenging cultural norms and the boundaries of taste.

Within some European contexts, the concept of festival itself is understood as problematic, a term that somehow reflects a broader cultural conformity and the erosion of local community interests. MediaWave, for example, in Györ, Hungary, is a multi art form event that has no city funding and now presents itself as a "gathering" in an old fort on the edge of a river. About half of the programme is pre-organised and the rest is spontaneous self-expression providing a framework that facilitates ad hoc art to be created instantaneously. Whilst the music at MediaWave is not exclusively jazz-based, the politically motivated and spontaneous nature of the event reflects the aesthetic of improvisation, a desire to represent local interests, to retain ownership of local heritage, and to resist top-down formations of culture. ${ }^{4}$

\section{Re-engaging with a National story, subverting dominant histories}

inclusive in their approach to programming and event management. Keychange is an international campaign which invests in emerging female talent whilst encouraging festivals to sign up to a 50:50 gender balance pledge (in relation to programming and commissions) by 2022. See https://keychange.eu.

${ }^{4}$ For further information on Mediawave see http://www.europejazz.net/european-jazzconference-2015-ejn-ga-report. 
Regev's work, above, highlights the way in which festivals have an ability to engage with dominant histories bound up with nation. In the case of the Red Sea Festival, the cosmopolitan content of the festival programme provides an alternative model of culture from which to write a national story. A more overt and playful engagement with national history can be found within the conception of the Down with Jazz festival in Dublin, which subverts the sentiment of the Catholic church and the 1934 anti-jazz movement in defining itself. The festival aims to take "a tongue-in-cheek look back to 1930s Ireland when jazz and 'foreign' music was seen by the Church as a filthy force of corruption, which culminated in a repressive 'anti-jazz' campaign to ban jazz music from the dance halls and airwaves of Ireland." The Catholic priest, Fr. Conefrey famously led a group of parishioners down the main street in Mohill's, County Leitrim, on New Year's Day in 1934, whose banners included inscriptions such as "Out with Paganism" and "Down with Jazz." Down with Jazz offers a parodic subversion of these historical events, and the festival provides a perfect platform for audiences to re-engage with history at the same time as celebrating the cosmopolitan character of Ireland today. The festival space itself, located within the tourist area of Temple Bar in Dublin, also invites a playful engagement with history, as audiences are invited to take selfies in front of a mock-up 1930s cottage whilst the deceased Fr Conefrey (aka, the festival communication team) posts tweets in disgust of the festival audience's supposedly suggestive and demoralising behaviour.

\section{Heritage as a form of reconciliation}

We might also think of the jazz festival as a site for reconciliation where different identities can come together. An example of this can be found within Jazz Fest Sarajevo, founded just over a year after the end of siege of Sarajevo in 1997. Event founder and Festival Director Edin Zubčević was a Professor of Philosophy and Sociology prior to the Bosnian war but the conflict compelled him to change his career path. In an interview, Zubčević stressed the need to do something following that war that had some kind of social impact. He felt that there was not only an obvious need for reconciliation within the city - he stressed that that was necessary at the time and still very necessary - but also that the creation of cultural content was needed within the city that would provide people with some kind of aesthetic encounter that was different from peoples' experience of everyday life. Zubčević states:

I had the idealistic idea to celebrate freedom by creating an international jazz festival, as jazz for me is the music of the free man. My idea was to build a festival to celebrate differences because every single festival - if it's a good festival - should do this and, post-war, we are still living in a troubled multicultural society. Our main stage is in an ex-Jewish temple in a middle of a town surrounded by other mosques and churches, so for me it's the perfect setting. The music I wanted to present was different itself, and the musicians

\footnotetext{
${ }^{5} \mathrm{http}: / /$ www.improvisedmusic.ie/festivals/down-with-jazz
} 
were not only different from everyone else but diverse amongst themselves too. (Goh 2016)

Here, Zubčević comments on the way in which locations, buildings and sites reflect cultural, political, and religious differences, and how the festival provides a means of bringing people together and engaging with difference.

\section{Heritage as a vision of the future}

When viewing cultural heritage discursively, it is perhaps as important to think about the future as it is the past. As Smith (2006) argues, heritage enables us to celebrate and understand not only who we are but also what we want to be. Within a jazz festival context, visions of the future can also be embodied in programming decisions as well as the spaces that festivals occupy. This could include uses of cutting edge technology and the ways in which festivals are mediated in digital space, as well as festivals that utilise the modern architecture of buildings in order make a statement about music and place. Moreover, visions of the future could also involve a challenge to the concept of festival itself and its relationship to place. The annual 12 Points festival, for example, aims to celebrate the next generation of artists by showcasing twelve bands from twelve different European countries. Interestingly, the event location alternates between Dublin and other European locations in order to promote networking and a sense of connectedness in Europe. Previous editions have included festivals in Umea, Porto, Stavanger and San Sebastian, the latter event staged in partnership with the Jazzaldia Festival. As a festival concept, 12 Points challenges the idea of festivals being singular entities rooted to particular places and spaces and, instead, has used the festival as a means of promoting European mobility, collaboration and cultural exchange.

\section{Discussion}

More broadly, when considering heritage discourse as inviting an imagined future, the festival becomes an ideal place to engage in utopian thinking. Utopia has been widely discussed as both an appealing and dangerous concept wrought with problems and idealised assumptions (De Geus 1999). However, within studies of festival cultures, there seems a natural synergy between festivals and utopian concepts, given the transformative potential of places, spaces and social practices within evanescent events or carnivalising atmospheres. Indeed, within McKay's recent edited collection The Pop Festival (2015) concepts of utopia form a central theme within the book, and within his introduction, he outlines ways in which contributors explore concepts of utopia in contrasting ways; for example, as something celebrated, critiqued, glimpsed, denied, dreamt or nightmared. And yet, despite these contrasts, McKay stresses that "[Festival], at its most utopian, is a pragmatic and fantastic space in which to dream and to try another world into being" (5). Rather than utopian thinking being founded on idealised principles, the concept can provide a critical framework from which to challenge established conventions, political practices and naturalised assumptions about the world. Within a jazz context, utopia can be useful when it provides a means 
of challenging presuppositions, encouraging a continual sense of reflexivity about the music's ontology and its cultural relevance, and keeping the present in dialogue with the past.

This typology is not designed to be exhaustive but it does aim to open up a space where new voices can emerge. Through the work of the CHIME project, we have come to understand how jazz festivals can speak to different heritage issues and give voice to different groups, ranging from the disenfranchised to the privileged middle classes. By viewing jazz festivals through the lens of cultural heritage, we can begin to challenge reified presentations of heritage that promote uncomplicated interpretations of nations, people and their associated cultural narratives. Festivals offer meaning to specific groups through acts of remembrance or commemoration, they have the potential to engage with a multitude of voices, and their locations enable people to negotiate a sense of belonging or to (re)consider their place in the world. By engaging with issues of race, gender, disability and class conflict, the jazz festival space can become the ideal place for resounding: resounding the past, resounding the present, and the critical issues that shape the politics of everyday life.

\section{Acknowledgements}

This work was supported by JPI Heritage Plus. I would like to thank the CHIME project team for their creative input into this work and members of Europe Jazz Network for their cooperation and participation in this research. 


\section{References}

Boyd Raeburn, Bruce. 2009. New Orleans Style and the Writing of American Jazz History. Ann Arbor: University of Michigan Press.

Bennett, Andy. 2009. "Heritage Rock: rock music, representation and heritage discourse." Poetics 37 (5-7): 474-489.

Brandellero, Amanda. and Jansen, Susanne. 2014. "Popular Music as Cultural Heritage: scoping out the field of practice." International Journal of Heritage Studies 20(3): 224-240.

Cohen, Sara. 2012. "Musical memory, heritage and local identity: remembering the popular music past in a European Capital of Culture." International Journal of Cultural Policy 19(5): 576-594.

Davenport, Lisa. 2013. Jazz Diplomacy: Promoting America in the Cold War. Jackson: University Press of Mississippi.

De Geus, Marius. 1999. Ecological Utopias: Envisioning the Sustainable Society. Utrecht: International Books.

Falassi, Alessandro. 1987. "Festival: Definition and morphology." In Time out of Time, edited by Alessandro Falassi, 1-10. Albuquerque: University of New Mexico Press.

Gebhardt, Nicholas, and Whyton, Tony, eds. 2015. The Cultural Politics of Jazz Collectives: This Is Our Music! New York: Routledge.

Goddard, Chris. 1979. Jazz Away From Home. London: Paddington Press.

Goh, Fiona. 2016. "Strength in Numbers II: A Study of Europe Jazz Network." http://www.europejazz.net/activity/strength-numbers

Hall, Stuart. 1999. 'Whose Heritage? Unsettling 'The Heritage', Reimagining the Post-Nation' Third Text 13:49: 3-13.

Heller, Michael. 2017. The Loft Scene: Improvising New York in the 1970s. Berkeley: University of California Press.

Lake, Steve, and Griffiths, Paul, eds. 2007. Horizons Touched: The Music of ECM. London: Granta Books.

McKay, George, ed. 2015. The Pop Festival: History, Music, Media, Culture. London: Bloomsbury. 
McKay, George. 2005. Circular Breathing: The Cultural Politics of Jazz in Britain. Durham and London: Duke University Press.

Nicholson, Stuart. 2005. Is Jazz Dead? (or has it moved to a new address). New York: Routldege.

Prouty, Ken. 2013. Knowing Jazz: Community, Pedagogy, and Canon in the Information Age. Jackson: University Press of Mississippi.

Regev, Motti. 2011. "International Festivals in a Small Country: Rites of Recognition and cosmopolitanism." In Festivals and the Cultural Public Sphere edited by Liana Giorgi, Monica Sassatelli, and Gerard Delanty. New York: Routledge.

Sakakeeny, Matt. 2013. Roll With It: Brass Bands in the Streets of New Orleans. Durham and London: Duke University Press.

Smith, Laurajane. 2006. Uses of Heritage. New York: Routledge.

Von Eschen, Penny. 2006. Satchmo Blow Up The World: Jazz Ambassadors Play the Cold War. Boston: Harvard University Press.

McKay, George, and Webster, Emma. 2016. "The Impact of (Jazz) Festivals.” Jazz Research Journal 9 (2): 169-193.

Williams, Martin. 1993. The Jazz Tradition. New York: Oxford University Press.

Whyton, Tony. 2012. "Europe and the New Jazz Studies.” In Eurojazzland edited by Luca Cerchiari, Laurent Cugny, and Franz Kerschbaumer. Boston: Northeastern University Press.

Zanten van, Willem. 2004. "Constructing New Terminology for Intangible Heritage." Museum International 56 (1): 36-44. 